This is a so-called personal version (author's manuscript as accepted for publishing after the review process but prior to layout and copyediting) of the article: Ritvala, T. and Granqvist, N. (2009).

Institutional Entrepreneurs and Local Embedding of Global Scientific Ideas - The Case of Preventing Heart Disease in Finland. Scandinavian Journal of Management, 25 (2): 133-145.

Researchers are kindly asked to use the official publication in references.

\title{
Institutional Entrepreneurs and \\ Local Embedding of Global Scientific Ideas \\ - The Case of Preventing Heart Disease in Finland
}

\author{
Tiina Ritvala* \\ Nina Granqvist \\ Department of Marketing and Management \\ Helsinki School of Economics \\ P.O. Box 1210 \\ FI - 00101 Helsinki
}

*Corresponding author. Tel.: +358 403538352

E-mail addresses: tiina.ritvala@hse.fi (T. Ritvala), nina.granqvist@hse.fi (N. Granqvist). 


\begin{abstract}
Investigating the activities of institutional entrepreneurs at the intersection of local institutions and global influences in the context of science-based fields is necessary for further development of the institutional entrepreneurship approach. We draw on complementary insights from the literatures on institutional entrepreneurship, Scandinavian Institutionalism, social/intellectual movements and spatial scales to study the activities of scientists in the local institution of global scientific ideas. Building on a qualitative case study, a globally pioneering heart health initiative in Finland, we found that the scientific profession regulates agency in science-based fields; that the holistic view of scientists is necessary to understanding mobilization activities in this context; and that the capacity of scientists to operate across spatial scales defines their capability for institutional entrepreneurship.
\end{abstract}

Keywords: institutional entrepreneurship, translation, spatial scales, science-based fields, community action, functional foods 


\section{Introduction}

The debate around the role of agency in institutional theory, i.e. the ability of actors to envision and enact changes in institutions (Holm, 1995), is intensifying in the key journals devoted to the study of organizations and management (e.g. Garud, Hardy \& Maguire, 2007; Edwards \& Jones, 2008; Maguire \& Hardy, 2009). We contribute to this debate by further developing the concept of institutional entrepreneurship and by merging conceptual ideas from related literatures to strengthen its analytical foundation. The institutional entrepreneurship approach (DiMaggio, 1988; Fligstein, 1997; Beckert, 1999) has addressed agency in the context of the emergence of various fields from different perspectives including, what role do the formal position and activities of institutional entrepreneurs play in field emergence (Maguire, Hardy \& Lawrence, 2004; Perkmann \& Spicer, 2007), and how institutional entrepreneurs participate in shaping the boundaries and creating shared understandings of a field (Rao, 1998; Lawrence \& Phillips, 2004; Maguire et al., 2004; Munir \& Phillips, 2005) and in the development of novel standards, policies, and practices (Garud, Jain \& Kumaraswamy, 2002; Lounsbury \& Crumley, 2007; Wijen \& Ansari, 2007). The concept has gained increasing support among neoinstitutional scholars as a viable way for explaining institutional renewal. However, existing studies tend to concentrate on narrow geographical settings, neglecting both the interaction between local institutions and global influences in the process (Scott, 2001; Morrill, 2007). We argue that a focus on a single institutional context neglects the investigation of the links to broader societal changes, and risks overemphasizing the role of local issues and actors, rather than seeing them as local variants and enactors of globally circulating ideas.

Furthermore, in the institutional entrepreneurship approach there remains a peculiarly scarce understanding of the role of agency in science-driven institutional change. We believe this is due to the curious neglect of science-based fields as objects of empirical inquiries. As a result, there is little empirical evidence on who are the institutional entrepreneurs in science-based fields, and through which activities they institute novel fields. We define science-based fields as domains of activity where progress in science and the scientific profession play a major role in the structuration of the field. Science-based fields are a particularly interesting case for the investigation of agency and mediation of influences between different institutional contexts for various reasons. Firstly, it has been demonstrated that individual scientists play an important role in break-through discoveries, which induce paradigmatic changes within 
science, and may result in major institutional transformations in society (Hargadon \& Douglas, 2001; Zucker \& Darby, 1997). Secondly, scientific communities tend to be global, which adds to their complexity, and to the importance of studying how novel scientific ideas travel globally, and how they become embedded in local institutions. In previous studies science is conceptualized as a means for producing texts to build new institutions (Maguire \& Hardy, 2006); or as a cultural resource challenging old practices through new analytical theories and tools, which then institutionalize a new practice (Lounsbury \& Ventresca, 2002; Greenwood \& Suddaby, 2006). However, there are few studies on the processes through which global scientific movements lead to the emergence of local institutions.

In order to address such lacunae in the institutional entrepreneurship literature, we examine who are the institutional entrepreneurs in science-based fields, and how they mediate between global scientific communities and local social and political institutions. We develop the institutional entrepreneurship approach by merging conceptual ideas from other literatures. These include the notion of translation (Latour, 1986), which has been adopted into “Scandinavian Institutionalism” (Czarniawska \& Sevón, 2005); and the literature on spatial scales (Lefebvre, 1991; Leitner, 1997). These literatures are employed to create an understanding on the cross-spatial links in institutional emergence, particularly to cast light on the tasks of institutional entrepreneurs in embedding ideas from global communities to local institutions. The study builds on Latour's (1986) formulation, that the spread of any idea in time and space is in the hands of people who modify, interpret and appropriate it in different ways. In the context of our study, the agency of scientists is crucial in the translation of global scientific ideas in setting the scene for institutional change at local level. We borrow the concept of scientific/intellectual movements (Frickel \& Gross, 2005) to cast light on the special nature of mobilization of ideas in the context of science.

We empirically examine the community intervention program for the prevention of heart disease in North Karelia in Eastern Finland. The North Karelia Project involved a lengthy process that aimed to change grass-root understandings of the relationship between food and other lifestyle factors, and heart health. The project, launched in 1972, was triggered by an international scientific research program, and is now considered a globally important benchmark for a community intervention program. Our study investigates how the novel understanding of the diet-heart health relationship became adopted in Finland, and how local embedding and consequent activities resulted in the birth of a globally disseminating best 
practice for heart health community interventions. While chronic diseases, such as heart disease, are the major health burden in Western societies, they are increasing rapidly in the developing world due to demographic and economic transitions (Nissinen, Berrios \& Puska, 2001). This highlights the importance of studying the origins and dissemination of community prevention programs. The lessons learned in these programs may have important implications for resolving other contemporary issues, such as climate change, which also calls for broad community mobilization efforts.

Our findings contribute to the management and organization literature, and more particularly to the institutional entrepreneurship approach, in several ways. Firstly, the study adds to the scarce literature on the interaction between macro level structuring of institutions and micro level agency by discussing how local agents participate in the institutional work (Lawrence \& Suddaby, 2006; Edwards \& Jones, 2008) necessary for creating and leveraging groundbreaking scientific ideas. Secondly, the study develops the institutional entrepreneurship approach by investigating agency across spatial scales; that is, how agents identify and mobilize issues from their global communities to transform local institutions. Finally, the study casts light on the special nature of science-based fields as contexts for institutional entrepreneurship.

\section{Scientific and intellectual movements and spatial scales}

According to Hoffman (1999: 352), an organizational field is formed around "issues that bring together various field constituents with disparate purposes”. Science-based fields represent a type of organizational field regulated by the profession and institutionalized practices of science. Novel science-based fields typically have their origins in scientific and intellectual movements (SIMs). SIMs are "collective efforts to pursue research programs or projects for thought in the face of resistance from others in the scientific or intellectual community", which have "a more or less coherent program for scientific or intellectual change or advance” (Frickel and Gross, 2005: 206). According to Gieryn, Bevins and Zehr (1985), scientific development depends on the profession of experts, who have a specialized training and institutionalized legitimacy to decide upon the validity of knowledge claims. They argue that scientists are critical to any claims of knowledge, and "reach consensus over facts or theories that are accorded at least provisional status of truth” (p. 402) through a process of disinterested search for knowledge. From time to time the scientific 'truths' are 
challenged through SIMs able to present evidence that destabilizes current scientific beliefs. This may give incentive for institutional level changes, even to the extent where the Kuhnian notion of "paradigm shift” materializes (Kuhn, 1962). Frickel and Gross (2005) suggest that intellectual leaders are major drivers of SIMs as their task is to articulate its program and conduct the intellectual or scientific work that comes to be seen as the hallmark of the movement.

While there are a variety of scientific and intellectual movements challenging the accepted truths within given fields, it is only some of them that gain acceptance as mainstream science and have an impact to the society at large. This study aims to cast light on how agents operating within a SIM are able to induce such shifts. Furthermore, scientific communities typically emerge in local contexts, but over time tend to become transnational as the community's ideas spread through conferences, journals, research collaboration and informal communications (Haas, 1992), thus stretching the communities across time and place (Bunnel \& Coe, 2001). In our investigation of the interplay between global ideas and local agency we employ the notion of spatial scales. This refers to a socially produced (Lefebvre, 1991), nested hierarchy of bounded spaces of differing size, such as local, national and supranational (Leitner, 1997). Various streams of research examine the role of firms and professions for instance in consulting and accounting, as mediators between various localities (Greenwood \& Suddaby, 2006; Guler, Guillén, \& Macpherson, 2002; Ainamo \& Tienari 2002). However, there is little research on how the activities of experts within globally extending scientific communities create embryos of novel local institutions.

Therefore, an aspect of scientific and intellectual movements that this paper investigates is the flow of ideas from global scientific communities to local contexts, their embedding in local institutions, and the impact of locally modified ideas to the development of the global community. We argue that institutionally active members of scientific communities create a mediating layer between global scientific movements and local institutions. Individual scientists draw from the ideas present in their global community, and embed them locally through their research, teaching, and policy activities. This takes place regardless of whether they represent the dominating view of science or a challenging scientific movement. Hence, through belonging to global scientific communities and by engaging in various activities locally scientists form part of the spatial scales. From this idea it follows that there is a need 
to understand the mechanisms through which individual scientists mediate influences between local and global scales.

\section{Agency and translation across scales}

Scandinavian Institutionalism, by drawing on the notion of translation (Latour, 1986), has produced detailed narratives on adaptations of foreign ideas and institutions to local contexts (Czarniawska \& Joerges, 1996; Czarniawska \& Sevón, 2005; Lindberg \& Czarniawska, 2006). In the translation literature, ideas are perceived as entities created in interaction among multiple stakeholders. Therefore, while a scientific idea may take root in the mind of a scientist, (s)he must persuade other members of the scientific community to adopt it. Through publications and embedding in discourses, scientific ideas can gradually attain a greater objective status which make them more transferable across time and space (cf. Czarniawska \& Joerges, 1996).Translating agents localize ideas by strategically and collectively reframing them to fit local circumstances; this facilitates resource mobilization, implementation and transfer (Boxenbaum, 2006). As a result, the new form ideas take, which reflect specific local institutions (Lawrence \& Phillips, 2004), and political and social issues, is different from forms elsewhere. In this "local labeling” task (Czarniawska \& Joerges 2005: 32) in sciencebased fields, we argue that the ability of scientists and public policy actors, in particular, to carry knowledge (Bunnell \& Coe, 2001; Amin \& Cohendet, 2004) and articulate discourses (Spicer, 2006) from one space or scale to another, is crucial. Spicer (2006) discusses how actors rescale struggles over certain issues within a spatial scale by connecting them to discourses on the same, lower or higher scales. For example, the public health issue may represent a higher scale discourse, whereas the issue of heart disease mortality in a provincial community is an example of a lower scale, more specific discourse. Such local issues may, again, have implications in shaping the higher level discussions on health. In a similar manner, actors in scientific communities are subject to scientific ideas present in, and applicable to, different scales, and may rescale them to address the local context, audiences and issues.

According to Lippi (2000), the role and influence of socializing agents, who locate at local rather than at macro level, are perhaps more important than the actual idea to be translated. The task of such agents is to construct an issue locally and frame it so that a clashing of interpretive understandings is avoided (Benford \& Snow, 2000), and cooperation, motivated 
by shared identity and interests, can be fostered (Ansell, 1997). Particularly in scientific communities convincing of peers depends on the availability of scientific evidence, which is plausible and relevant to the scientific community, and is able to sufficiently challenge dominant scientific beliefs. Translating scientific results into action requires the construction of the scope and relevance of events and ideas that both create and justify an issue and enable the development of novel local institutions. From the institutional entrepreneurship perspective, this is the very task of institutional entrepreneurs. The SIM literature helps us to understand the special characteristics of institutional entrepreneurship in science-based fields, whereas the literatures on spatial scales and translation focus attention to the importance of micro level agency and institutional work in instituting globally circulating scientific ideas at the local level.

Many accounts of translation focus on studying the spread of American managerialist practices around the globe (e.g. Buck \& Shahrim, 2005). This dominant focus unnecessarily restricts empirical pluralism (Glynn, Barr \& Dacin, 2000) and may limit the variety of translation mechanisms identified in the extant literature. In the empirical section, we study the processes of translation and mobilization of issues within the context of Finland to generate further knowledge on the global-local links in the emergence of novel science-driven issues and practices. The empirical case of North Karelia Project is an example of a sciencedriven community intervention program, originating in the transnational scientific community, and later becoming a benchmark for further intervention programs on heart health.

\section{Data and methods}

\subsection{Research context}

After World War II, new public health problems emerged in industrialized countries. These principally came as a product of the increased wealth in societies. They were perceived as diseases of affluence. The spread of heart disease among middle-aged men posed a particular major challenge. Finland was badly effected; in the 1960s, the country suffered from the world's highest rate of coronary heart disease (Puska, 2008). The North Karelian population in Eastern Finland suffered from an unusually high number of heart attacks, which was believed to relate to unhealthy lifestyles. The North Karelia Project was launched in 1972 by 
Finnish authorities and experts, with the help of the World Health Organization WHO, to reduce the high cardiac mortality rate in that region. The aims of the project were to improve the detection and control of hypertension, to reduce smoking, and to promote diets lower in saturated fat and higher in vegetables and low-fat products (McAlister, Puska, Salonen, Tuomilehto, \& Koskela, 1982). To enforce such fundamental changes, a multidisciplinary approach was called for. In addition to medicine, knowledge of sociology, social psychology and social policy were crucial in creating behaviour modification (Mustaniemi, 2005). This involved in-depth cooperation with American scientists, such as professors Everett Rogers in innovation-diffusion and Alfred McAlister in social psychology.

The project only initially addressed the province of North Karelia, a rural county in Eastern Finland with 180000 inhabitants. After the initial five year period from 1972 to 1977, the project was adopted at the national level because of its encouraging results. By the end of the original project in 1997, the mortality rate from heart disease was reduced by over 80 percent among the 35-64 year old male population in North Karelia (Puska, Vartiainen, Laatikainen, Jousilahti \& Paavola, 2009). The launch of the North Karelia Project marked a watershed in the development of community interventions for heart health promotion globally. With the smaller scale "Stanford Three Community Study”, (conducted between 1972 and 1975 and led by John Farquahar) ${ }^{1}$, the North Karelia Project set the stage for subsequent populationbased community intervention trials such as the Minnesota Heart Health Program and the Pawtucket Heart Health Program (Institute of Medicine, 2001). Within the literature on community-based disease prevention, the North Karelia Project is viewed as the best practice case study, and the project model has spread across the globe (McLaren, Ghali, Lorenzetti \& Rock, 2007).

The North Karelia Project provides an intriguing empirical context for research. The project has its origins in the findings and discussions within a transnational scientific community. The project provided the catalyst for significant local institutional change, which has had a major impact on public policy both locally and globally. It also made important contributions to scientific knowledge. An examination of this case provides new insights into the agency underlying the collective mobilization resulting in the emergence of novel science-driven practices. Consequently, the study gives many theoretical implications for the research on

\footnotetext{
${ }^{1}$ The organizers of the Stanford study and North Karelia Project were not initially aware of each other (Mustaniemi, 2005).
} 
institutional change and institutional entrepreneurship from a spatial perspective. In the subsequent sections, we outline in detail the community building activities that took place in order to combat heart disease. We also investigate how these processes in Finland were linked to developments elsewhere.

\subsection{Research design and data}

We use a single case study approach (Siggelkow, 2007; Stake, 2005) which is suitable for building theory (Dyer and Wilkins, 1991) on institutional entrepreneurs as translating agents. Lawrence, Hardy and Phillips (2002) suggest that qualitative approaches are appropriate for examining the localized dynamics of institutional change. Understanding institutional entrepreneurship as a process that takes place across spatial scales necessitates detailed, interpretive analyses, which take into account the specific contexts in which the translation activities occur (Garud et al., 2002; Maguire et al., 2004; Maguire \& Hardy, 2009). Furthermore, the study of globally disseminating practices calls for the use of qualitative methods to uncover what is actually being transferred (Tempel \& Wagenbach, 2007). We employ a historical case study approach where we conduct a qualitative historical analysis in order to help us identifying key events and actors in the North Karelia Project, and how these were related to developments outside Finland.

By investigating the activities of different types of organizations and individuals in detail, we respond to the recent scholarly calls for multi-level empirical research. Such approach is needed to enrich management studies, which is traditionally dominated by single-level studies (Hitt, Beamish \& Jackson, 2007). We also employed the idea of systematic combining (Dubois \& Gadde, 2002), where theoretical framework, empirical framework and case analysis co-evolve. Accordingly, during the research process, suitable theoretical approach was identified through empirical insights while, at the same time, empirical insights emerged from the theory (Dubois \& Araujo, 2004). Echoing Van Maanen, Sørenson, and Mitchell (2007), the interaction between conceptual and empirical planes underlies discovery. This emergent research design enabled us to refocus our research question and redefine the boundaries of the case study in the course of the research process.

We collected data from several sources, including interviews, project reports, academic publications explaining the method of project, and books. The primary data consists of 34 
interviews which we undertook between August 2004 and March 2008. Each interview lasted typically between 1 and 1.5 hours. Informants included representatives of the North Karelia Project staff; university professors in medicine; food chemistry and functional foods; representatives of public agencies; informants from small start-ups and large multinational firms; and consultants. Different types of questions were asked, depending on the informant's background. For example, project staff interviews sought to elicit understanding of the strategies that were used to mobilize community and business support for the project, key challenges faced during the project, and how the project was linked to developments within the global community investigating heart disease. The role of the interviews was to obtain from participants their own accounts of how the events unfolded, as well as their perceptions of the roles and motivations of other project participants. The rest of the interviews aimed at learning about the impact of the project on research and business priorities as well as public policies. All interviews were recorded and transcribed before the analysis. We acknowledge the potential for bias in our interviews with the key informants being susceptible to ex-post rationalization with the possibility of boosting their own role in the process. For instance, an event may be mentioned by an informant because of rhetorical convenience as a "logical starting point for a story that is being told” (Czarniawska \& Joerges, 2005: 27). However, a diverse range of informants, and an extensive collection of secondary data, provide a more balanced perspective.

The key principles and results of the North Karelia Project are broadly documented in international journal articles, which assist the verification of data consistency. Since the project aimed to decrease the cholesterol level among the entire Finnish population, it is particularly well documented in Finnish newspapers, academic journals, project reports and books. For example, two histories written on the project that are based on the experiences of the authors and dozens of people involved were important sources of evidence (see: Mustaniemi, 2005; Puska et al., 2009). We also examined an extensive number of articles published in medical journals and a range of documents published by the World Health Organization (WHO). Furthermore, we used PubMed, a Web-based publication database for medical science that includes over 17 million citations starting from the 1950s. Analysis of this data helped us to investigate the spread of the North Karelia Project approach within the medical community, and to discover the authors who disseminated the ideas. Table 1 presents the chronology of key events, and provides quotations from our interviews exemplifying the 
global-local-global links and other data sources used in the identification and analysis of the events.

\section{< ADD TABLE 1 ABOUT HERE >}

\subsection{Data analysis}

The data analysis is comprised of three main stages. Firstly, we traced the development of community-based heart health promotion programs globally as well as in the Finnish context. Both secondary data and interview data were used to construct retrospective event histories where we mapped the key events and actors in community interventions for heart health. Table 1 provides an overview of the key events. In the second stage, we identified the key actors who mediated influences between local and global scales in the emergence process. To identify an institutional entrepreneur we followed Garud et al. (2007: 962), "to qualify as an institutional entrepreneur an individual must break with the existing rules and practices associated with the dominant institutional logic(s) and institutionalize the alternative rules, practices or logics they are championing”. The interaction between events, actors, and acts of translation, that took place during the mediation of knowledge on heart disease prevention to and from the Finnish context, were the building blocks for our theorized storyline (GoldenBiddle \& Locke, 2006). We acknowledge that it is our interpretation, and those of our informants, which turns happenstances into events (Munir, 2005). In this form of contextualist analysis various events are products of action, and change is neither linear or singular but takes place at multiple interconnected levels (Pettigrew, 1990; Seo \& Creed, 2002). In the context of our study, this means that institutional entrepreneurs act as motors of institutional change, but they neither exist nor work alone in a vacuum, rather they mediate influences across scales, between local and global, and from grassroots to policy-makers.

In the following, we discuss the agency of institutional entrepreneurs as translating agents in three sections: firstly, inward translation through local interpretation of research results and globally acknowledged issues; secondly, local community and movement creation; and thirdly, outward translation enabled by the reputation and institution of North Karelia Project as a best practice case in community interventions for health promotion. 


\section{Agency, spatiality, and prevention of heart disease through community action}

\subsection{North Karelia Project in a global context}

In 1945, a young Finnish Physiologist Martti J. Karvonen commenced physiological studies of woodcutters in Eastern Finland who, although engaged in hard physical work, had died from heart disease. This raised theoretical puzzles as it was already understood that physical activities enhances health and prolongs life. In 1947, a demographer, Väinö Kannisto, published his doctoral thesis in which he was able to show that mortality in the eastern regions of Finland had been higher than in the west since the $19^{\text {th }}$ Century, and that heart disease deaths were particularly common (Karvonen, 2009). It became obvious that something was seriously amiss in the scientific understanding of the causes of heart disease.

Elsewhere in the 1950s, Physiologist Ancel Keys of the University of Minnesota was searching for scientific evidence on the link between fat intake, blood cholesterol and heart disease. Keys' sabbatical year at Oxford in 1951, and related travels in Europe, opened his eyes to cultural differences in diet, behaviours, and heart disease risk. Keys had also become frustrated with the limitations of laboratory experiments and called for a more population oriented research. In 1952, Keys published his hypothesis on the chain of causation: dietary fat causes high blood plasma cholesterol, which causes atherosclerosis, i.e. heart disease. In the spring of 1954, Karvonen visited the Laboratory of Physiological Hygiene of the University of Minnesota, and had a short discussion with Keys, who had just returned from Italy. Karvonen and Keys became convinced that the case of Finland would provide a novel understanding of risk factors for heart disease. Their encounter provided the decisive stimulus for them to join forces in 1956 to study heart disease risk factors. This so-called 'East-West Study' formed a part of the pre-study of the famous "Seven Countries Study" launched in 1958. In this classical study the cross-country variation of mortality rates from heart disease was monitored for over thirty years in Finland, Greece, Italy, Japan, the Netherlands, USA and Yugoslavia. (Mustaniemi, 2005; Blackburn, 2006; Karvonen, 2009). The study provided important evidence that a diet rich in vegetables, fruit, dietary fibres and olive oil, and low in saturated (animal) fat was beneficial for heart health. The data that were collected in the Seven Countries Study created the basis for a novel movement within medicine. This movement was also reflected in the popular press, for example, in January 1961 Keys 
appeared on the cover of Time Magazine ${ }^{2}$ in a special issue on "Diet \& Health", where he was nicknamed “Mr. Cholesterol”.

By the late 1960s, there was a clear need for studies investigating the possible prevention of heart disease through risk factor intervention. In 1970, the Geneva Office of WHO and Dr. Zbynek Pisa organized a meeting in Rome to discuss possible approaches to the matter (Mustaniemi, 2005). One of the identified prevention strategies was a community intervention trial where the target of the intervention was entire regions and populations rather than individuals at high risk of heart disease. The North Karelia Project was to be the first comprehensive community-based intervention for heart health.

\subsection{The creation of new practices and concepts through local mobilization}

In 1970, in response to the summary and conclusions of 10-year follow-up study of the EastWest study demonstrating extremely high rate of heart disease mortality, the Regional Governor of North Karelia, Esa Timonen, invited all North Karelian members of the Finnish parliament and several representatives of official and voluntary organizations to form a pressure group (Karvonen, 2009). A petition for state aid was signed in January 1971 to get urgent help to North Karelia. This whole bottom-up mobilization process was to a great extent initiated by the women of North Karelian who actively voiced concerns about the premature death of their husbands. This issue created a severe social problem as children were losing their fathers and households their income. Critical voices were also heard at a local press conference where the results of East-West study were released. Our interviewee recalls:

I remember when a member of the audience asked: "You come here every five years to tell us how sick we are, but when will you start doing something?” (Director and Principal Investigator of the North Karelia Project)

The North Karelia Project was launched in 1972 by Finnish authorities and experts, with the assistance of WHO. In the beginning, the support of WHO consisted of various types of expert help and training trips abroad for key project staff (Puska, 2009). There was mutual interest in preventive cardiology and in order to assist finalization of the project plan WHO sent four international experts to the planning seminar held in September, 1971: Z.Fejfar

\footnotetext{
${ }^{2}$ http://www.time.com/time/covers/0,16641,19610113,00.html
} 
(Geneva), J.N. Morris (London), Z.Pisa (Copenhagen), and H. Blackburn (Minneapolis) (Karvonen, 2009). As time passed, close professional and personal ties developed between WHO representatives and the key project staff. WHO thus provided a key channel for close interaction between the North Karelia Project and global scientific and the policy community.

At the beginning of the project, both its ideological and methodological appropriateness was strongly questioned by many traditional cardiologists. This contestation took place at the level of the global medical community where not all scientists were convinced of the ethics of influencing people's dietary habits. This struggle was reflected earlier in Swedish scientists' decision not to participate in the Keys' study (see Weinehall, 2003). The issue was also reflected in a normative response that the project staff, mostly made up of young medical doctors, received from a prominent member of the medical community:

I remember him saying: "Son, atherosclerosis is a normal age related phenomenon, which can't nor even should be tackled.” (Co-principal Investigator of the North Karelia Project)

Hence, there was a struggle between the old guard, dedicated to preserving the established scientific beliefs and methodologies, and the new guard of scientists that had radically different views and approaches. The central axis in this debate was the traditional cure versus the modern preventive orientation of health care. Furthermore, the concept of communitybased prevention was new and lacked legitimacy among cardiologists. This meant that, in the mature healthcare sector where professions are an important part of dominating institutions (Sundin \& Tillmar, 2008), finding a suitable and willing candidate to lead the project was not an easy task. A working group led by the Finnish Heart Association, which conceived a basic plan for the North Karelia Project concluded that "leadership of such a project was not a task appropriate for senior medical professionals likely to be preoccupied with other work, but was rather a make - or - break challenge for a younger candidate" (Karvonen, 2009: 17).

To follow this suggestion Karvonen found young enthusiastic people and gave them a full responsibility of the execution of the project. Pekka Puska, a young physician and social scientist, was chosen to serve as the Director and Principal Investigator of the project. Like other key members of the project staff, Puska was enthusiastic and radical in his thinking about the need for a preventive approach:

Young hooligans who were involved in the early 70s took a big risk as there was only early evidence that blood pressure, cholesterol, and use of tobacco might be 
the underlying factors [for heart disease]. (Co-principal Investigator of the North Karelia Project)

Puska played a crucial role in designing and applying the comprehensive heart disease prevention approach. Community intervention was designed to achieve population-wide behavioural change, particularly around dietary habits which favoured the use of salty and fatty foods. The idea was to change the whole social and material environment of the region where dairy farming was the major source of income. Given that the dietary habits were deeply rooted, both culturally and economically, mobilization had to occur at community and grass root levels. This involved work with many community organizations including NGOs, the private sector, and policy makers at the national level, for example to change the policy of subsidizing dairy and meat farmers based on the quantity of fat in their produce.

In order to ensure broad community participation, the project leaders and experts built on some basic principles of behavioural change and innovation diffusion. Everett M. Rogers, the founding father of innovation diffusion theory, was personally involved in the project (see Rogers, 2003). The project applied his innovation-diffusion model to disseminate new riskreducing lifestyles through ordinary community networks to reach individuals. The key strategy was the use of 800 lay opinion leaders, educated by a local housewives' association called the Martha Organization, to persuade individuals to change their dietary habits. North Karelian women played a special role in the project: besides pressuring its initiation two thirds of the lay workers were women (Puska, Koskela, McAlister, Mäyränen, Smolander, Moisio et al., 1986). This corresponds to the fact that in many societies females are more interested in health-related issues and more active in giving dietary advice. Changing the attitudes of women was crucial - it was believed that men would gradually follow (Mustonen, 2005). The general idea of using lay opinion leaders was to avoid too much expertise, which would enable the dissemination of the message in an understandable and popularized form.

The idea that dairy fat intake caused heart disease was naturally strongly contested by the North Karelian dairy farmers who felt that their interests were being violated. Puska's political background played a major role in breaking down this resistance. Puska was acquainted with Urho Kekkonen, the President of Finland. They were both members of the Centre Party, which was the leading political party in rural areas. Wearing down resistance also required persistence and frequent visits to the dairy farmers. Puska firmly believed in the importance of personal involvement. He called this 'boots-deep-in-the-mud' approach, 
meaning that the project staff left the laboratory and became involved in the daily life of people. Puska's inspirational leadership and his perseverance even in the middle of great challenges was, according to many participants including our interviewees, a key explanatory factor for the success of the project. However, while his dedication and charisma were certainly key assets, it is naïve to think that a single person could change the whole community. Rather, the broad mobilization and involvement of the diverse community stakeholders was crucial in the institutionalization of novel eating habits.

The contestation was later reflected in "the great fat debate" which took place in 1988 in the leading Finnish newspaper Helsingin Sanomat. The debate started when the biggest dairy products company in Finland, Valio, published a full page advertisement claiming that heart disease has decreased less in North Karelia than elsewhere in Finland, and that the North Karelia Project lied (Mustaniemi, 2005). This debate resembled an institutional war (Hoffman, 1999), in which Valio was engaged in defensive institutional work (Maguire \& Hardy, 2009) where it purposefully aimed at countering the disruptive change that the project had induced. Even though this debate was initiated as an open attack against the diet-heart disease hypothesis, the outcome was a rapid increase in cholesterol awareness by the general public. The contestation thus helped to further disseminate the message.

As a result of the intervention risk-related lifestyles and risk factors for heart disease decreased markedly during the original five-year study period. The longitudinal statistics demonstrated that the age-adjusted coronary heart disease mortality rate had fallen 73 percent in North Karelia between 1969 and 1995 (Puska, 1999). It is noteworthy however, that the exceptionally high initial mortality rate contributed to such an impressive improvement figure. This "hard fact" broke the resistance, demonstrating the power of numbers in institutional change projects (cf. Déjean, Gond, \& Leca, 2007) and in institutional embedding of novel scientific ideas. Furthermore, the involvement of the National Public Health Institute (KTL) gave the project the necessary authority and legitimacy at a national level. This support was essential because in Finland the public sector is responsible for providing health care services for all citizens, and hence, KTL was the highest expert body in the area of health.

The public health efforts in North Karelia produced a fertile ground for deeper universitygovernment-industry relationships, and for the development of heart-healthy foods. For example, in the late 1980s, a new vegetable oil was developed made of rapeseed that grows 
well in the Northern climate of Finland. In 1995, the world's first cholesterol-lowering functional foods margarine, Benecol, was launched in Finland. This innovation was triggered by a need of a Finnish forest products company to find a buyer for sitosterol, a surplus byproduct of its milling process, a product that was found to have cholesterol-lowering properties. Benecol was linked to the North Karelia Project through a large clinical trial and the trial was conducted within the project, which already had established an internationally recognized system for such experiments. The trial documented a 14 percent reduction in the 'bad' cholesterol level (low-density-lipoprotein, LDL) and the results were published in 1995 in the New England Journal of Medicine, the flagship journal in the field of medicine. Professor Tatu Miettinen, a distinguished expert on cholesterol metabolism, who also participated in the North Karelia Project, had a key role in the innovation. Over a number of years, Professors Puska and Miettinen were the central actors in building legitimacy for Benecol among both health care professionals and consumers.

\subsection{North Karelia Project as a global benchmark}

The North Karelia Project was a pioneer in the endeavour to find the connection between diet and heart health. Within the literature on community interventions for health promotion NKP is viewed as a success and it is the most cited model for other prevention trials (McLaren et al., 2007). The project has resulted in published over 400 internationally published medical articles and has also gained wide recognition through WHO publications (Puska, Tuomilehto, Nissinen \& Vartiainen, 1995; Puska et al., 2009). In their comprehensive investigation of scientific literature and "grey" literature (government and organizational websites) on community-based interventions published in English or French between 1990 and 2002, McLaren et al. (2007) found over 70 community-based interventions implemented worldwide. For each intervention, they selected one published article that provided most detail on methods. They found out that $67 \%$ of these studies made explicit reference to one of the early interventions (North Karelia, Stanford, Pawtucket or Minnesota) and that the North Karelia was the project cited most often. Not surprisingly then, the key investigators of the project are frequently invited speakers at worldwide scientific and business conferences.

We further assessed the international spread of the findings of the North Karelia Project by using PubMed and found that of the total 129 hits on the project Puska was the author or a coauthor of 79 articles. This signals that in science-based fields, central actors need to possess 
the will and capability to publish in scientific and other journals in order to raise a global interest towards an issue, or to build a hallmark position for their endeavours. In addition, the media seems to play a role in selecting particular names, praising their role in achievements, and labelling them as primus motors. Not surprisingly then, the success of the project has later been associated mainly with the activities of Puska even though there were other key scientists involved such as Jaakko Tuomilehto and Erkki Vartiainen, individuals who had both played crucial roles as Co-principal Investigators of the project. Currently Director General of the National Institute for Health and Welfare, Professor Puska became recognized for his achievements and was invited to build the WHO Global Strategy on Diet, Physical Activity and Health (2001-2003) and was appointed as President-elect of the nongovernmental organization World Heart Federation in 2006. In early 2008, he was granted a prestigious British award by the Rank Foundation worth GBP 75,000 “for his demonstration on a national scale, in Finland, of the dramatic success of the application of preventive nutritional principles to the conquest of coronary heart disease” ${ }^{3}$.

Overall, WHO has played a key role in supporting the design of the project and in its international translation. Initially, the organization provided support in the formulation of basic intervention principles and in providing legitimacy for the undertaking. For example, national mass media campaigns indicated that the project's ideas were endorsed by WHO, and this influenced peoples' beliefs (Gullotta \& Bloom, 2003). With regard to the program's international spread, in as early as 1976 a WHO meeting began to consider whether the principles of heart disease prevention in North Karelia could be applied in other countries and cultures. This was reflected in the organization's decision to select North Karelia as a demonstration site for best practices in public health. As a result, the "North Karelia Project: International Visitors' Programme” is organized semi-annually, by the National Public Health Institute. Since 1979, up to 2000 guests from more than 100 countries have participated in the program, where theoretical frameworks and practical strategies for disease prevention are disseminated through lectures, discussions and site visits.

In addition to Western countries, the basic principles of the project have been widely replicated. Since the 1980s the attention has turned to also promoting the community-based intervention approach in developing countries that are struggling under the dual burden of

\footnotetext{
${ }^{3}$ http://www.rankprize.org/news1.htm
} 
both chronic and infectious diseases, such as Chile and China, (Puska, Nissinen \& Vartiainen, 2009). However, framing the North Karelia Project model as a universal solution to the heart health issue is problematic. There are critical voices questioning the relevance of community programmes to developing countries (e.g. Ebrahim \& Smith, 2001). The study by McLaren et

al. (2007) argues that many contemporary community-based interventions replicate the North Karelia Project model without adequate adaptation to the unique context in question. Professor Puska responds to this criticism in our interview:

We've never wanted to say that the North Karelia Project should be implemented as such elsewhere. Rather we say that in Finland this has been done in this way and that the medical theory on the risk factors is correct, it works...And to the thousands of visitors during the past 30 years, we've always remembered to say that the aim of this course [International Visitors' Programme] is not to say what you should do, but we hope that you get ideas and more confidence on your work.

In conclusion, what started as a courageous, local attempt to tackle the heart disease issue in the early 1970s, has evolved into a mainstream community-based intervention approach with global awareness among cardiologists and the general medical community. Despite the contestation and institutional wars which took place during its development, the North Karelia Project is today widely portrayed and acknowledged as a best practice case.

\section{A framework for institutional entrepreneurs as translating agents between global scientific communities and local institutions}

Earlier work on institutional entrepreneurship (e.g. Maguire et al., 2004, Munir \& Phillips, 2005; Wijen \& Ansari, 2007) has analyzed the multiple roles and tasks of various agents in institution building, but has neglected science-based fields as an empirical context for studies. In this section, we discuss how the special nature of science affects the kind of agency necessary to institute novel scientific, social and political practices. We also elaborate on the role that cross-scale interactions, that is, the interaction between global scientific communities and local actors and institutions, play in the emergence of science-based fields.

Our case puts forward plentiful evidence suggesting that, for mobilizing novel scientific ideas, the identification and construction of an issue, around which discussions may revolve, and opinions may be expressed, is crucial (cf. Hoffman, 1999). When scientists create or 
participate in scientific disputes by challenging established epistemic theories and practices they may mobilize a collective support against the status quo, resulting in a novel scientific or intellectual movement (Frickel and Gross, 2005; Hensmans, 2003). Scientists are the actors who hold the legitimacy and status necessary to challenge existing institutionalized practices and beliefs from within (also Gieryn, 1983). In the context of science-based fields issues are construed at the intersection of debates in science and the social and political aims and needs present in the local institutional environment. The intellectual movement then acts as a driver for change in other institutionalized domains, such as policy and business.

We found that scientists are the actors whose participation is necessary when extending the meaning work to address other spheres of society. Mobilizing the novel medical paradigm required a "bridging position” (Maguire et al., 2004; Greenwood \& Suddaby, 2006) between academia, business, and the public sector, and across national borders. Consequently, the scientists inducing institutional change need to be active not only in science but also in other sectors of society (cf. Sundin \& Tillmar, 2008). Scientists also needed to step down from the balustrade of science and engage personally in translation and mobilization of a novel idea across multiple levels of society. Rather than following the Mertonian norms of science, such as disinterestedness and organized scepticism, institutional entrepreneurship in science-based fields conveys a more humanized image of scientists (cf. Mazur, 1987). This was reflected in the high level of personal involvement of key scientists, combined with their willingness and capacity to act initially with only limited evidence.

It is also to be noted that in this mediating task, the actors significantly shape the concepts to be translated both scientifically and politically. In order to mobilize an issue, which has its origins in a scientific discovery or debate, the scientific knowledge needs to be popularized. Popularization represents a particular form of translation necessary for science-driven institutional change, and stresses the importance of personal involvement by scientists. The empirical case suggests that the most efficient popularization of science is that which inspires both policy actors and laymen alike and, hence, creates both top-down and bottom-up pressures for change. Translation benefited from the clever use of the rhetoric of science. These include the statistics of diminishing mortality rates and their interpretation into socially and nationally important issues. Statistics, research reports and journal articles also represent scientific artefacts that had a major impact on social and political priorities within society and therefore, on what was being studied and publicly financed. Successful translation and agency 
led to virtuous cycles, which then seemed to invoke "hero" imagery of certain individual institutional entrepreneurs (cf. Lounsbury \& Crumley, 2007; Maguire, et al., 2004) who are visible in the ex post accounts on the project.

It is worth noting that regardless of scientists' central role in our empirical case, the key impetus and pressure for further change came outside of the medical community; from local people. Institutional work (Lawrence \& Suddaby, 2006) in science-based fields may also include a party which is able to connect the new institution to discourses on a lower scale (Spicer, 2006), in our case through the involvement of a popular NGO. This secured the high level of readiness of the community to embrace the intervention. We argue that the surrounding social and political environment of Finland played a specific role in the creation of fundamentally new understanding of the relationship between heart health and lifestyle. In this respect Finland represents an institutional environment which encouraged cooperation between industry, universities and government. This enabled innovation at the interface between disciplines and between public and private sectors. Finns were also willing to accept public health recommendations (McAlister et al., 1982), manifesting the importance of cultural setting favourable for community intervention. In the similar manner, the role of political context also was crucial. The membership of the project leader in the dominant political party of the province empowered the institutionally divergent activities. Hence, the ability of institutional entrepreneurs to mobilize advocates that enable institutional change and innovation seem to be partly tied to institutions of a country (cf. Zucker \& Darby, 1997; Collinson \& Wilson 2006). It is also to be noted that the novel ideas were strongly contested by some prominent members of the medical community, and by business leaders. We found that the contestation of the issue in the media created a drama which made the issue more visible and raised interest among the public. Consequently, contestation is arguably a significant driver for disseminating knowledge, and it induces novel translations of the issue at hand amongst a wider group of actors.

Regarding the mobilization across local institutions and global scientific communities, our case highlighted how the entrepreneurship and collaboration of only a handful of likeminded scientists across national boundaries created the key impetus for the emergence of a novel movement within science. These actors formed a mediating layer between local institutions and issues, and were also the key agents in global mobilization of novel scientific ideas. In order to do this, institutional entrepreneurs needed to strategically leverage a variety of 
information channels, such as academic journals and mass media, from the early sense making phase through to the global dissemination of the novel ideas. This is crucial, because in science-based fields final legitimation and institution building takes place at the level of the global community.

Earlier studies have emphasized that institutional entrepreneurs benefit from social and political skills to induce alliances between actors (Garud et al., 2002; Wijen and Ansari, 2007). We argue that in science-based fields such alliance-building capability has to occur across spatial scales; this is because SIMs are global or transnational rather than national by nature. Based on the findings of our case study we suggest that the capacity of an actor to operate across spatial scales, and to link local and national institutions and global scientific communities, is an important capability that defines the possibilities for institutional entrepreneurship in science-based fields. Owing to their formal training and activities scientists are particularly capable of working across spatial scales, and linking a global body of research into local competences and institutions, by acting as local legitimators and lobbyists. Drawing on our findings, we conceptualize institutional entrepreneurs in sciencebased fields as translating agents, who bridge spatial scales and are central actors in the identification and theorizing of local issues in which these ideas then become embedded. Our conceptualization is aligned with the increasing criticism of scholars on the overly rationalistic view on institutional entrepreneurs (Djelic \& Ainamo, 2005; Hwang \& Powell, 2005) and with the argument that institutional entrepreneurs cannot change dominant institutions unilaterally (Lounsbury \& Crumley, 2007; Wijen \& Ansari, 2007; Lawrence \& Suddaby, 2006). Building on our findings, we propose that the capacity of an actor to mediate between local institutions and global scientific communities by operating across spatial scales defines the possibilities for institutional entrepreneurship in science-based fields.

In Figure 1 we present the framework for institutional entrepreneurs as translating agents at the intersection of global scientific communities and local institutions. We identify four overlapping phases: 1) Active agents identify issues drawing on their knowledge of scientific facts and debates and local problems; and 2) confront dominant scientific theories and norms with early evidence gained from responding to local anomalies. 3) Local and national construction of these anomalies triggers multilevel mobilization of social and material resources, and leads to the forming of transnational or global scientific and intellectual movements. 4) When successful, translating activities culminate with leveraging and 
disseminating best practices and novel concepts in public policy context, and result in transferring the scientific practices and concepts from fringes to mainstream. Through translating activities between global scientific communities and local social and political institutions, in each phase institutional entrepreneurs play key roles.

\section{<ADD FIGURE 1 ABOUT HERE >}

\section{Conclusions}

This article advances the research on institutional entrepreneurship by discussing how individuals translate ideas from global scientific communities in to legitimate local activities that result in institutional change. By so doing, the study addresses agency in science-driven fields, a context which, despite its importance and theory building capacity, has yet caught the attention of scholars of institutional entrepreneurship. This conceptual and empirical focus on the complex interaction between agency, institutions, and spatial scales allows us to make several contributions to the literature.

Firstly, we contribute to neoinstitutional theory by studying institutional entrepreneurship in science-based fields and the public sector. These are contexts which have largely remained undertheorized. We found that in science-based fields agency is strongly regulated by the scientific profession itself through the mechanisms of legitimacy and reputation. This creates boundaries for the issues of, who can induce change, what methods they may use in the task, and how novel ideas may be leveraged from science to society at large. Therefore, our study casts light on the particular processes through which micro level agency relates to the macro level structuring of institutions in science-based fields (cf. Lawrence \& Suddaby, 2006; Edwards \& Jones, 2008).

Secondly, our findings suggest that institutional entrepreneurship in science-based fields necessitates deep personal engagement of motivated agents. This stresses a holistic view of scientists as individuals embedded in particular contexts, carrying specific grievances and motivations. Such focus challenges such streams of research within the sociology of science, where science is considered as a monolith, and scientists as a unified group of actors operating according to the same rules and values (cf. Moore, 1996). Our findings therefore put in question the notions of 'scientific purity' and the disinterestedness of scientists. Finally, 
through our investigation of the role of the surrounding social and political environment, and of the links among multitude of such environments, we respond to scholarly calls to understand the conditions under which embedded actors are both enabled and motivated to institute novel institutions (Seo \& Creed, 2002). In the context of science-based fields, we found that the very capacity of scientists to operate across a multitude of spatial scales, in addition to connecting sectors and disciplines in the local context, defined their ability for institutional entrepreneurship. Therefore, the study further advances a view according to which institutionalization is not only a top-down phenomenon of institutional isomorphism, but rather, it works also from the micro to the macro, and from the local to the global (Barley \& Tolbert, 1997; Lippi, 2000).

Our study has limitations which provide ideas for further research. While our single case study approach enabled theory building on institutional entrepreneurship in the context of a science-based field, it also limits the generalizability of research findings. Whether the various actors in different contexts employ similar strategies when acting as translating agents across local and global scales, or whether it matters if translating agents are embedded in public or private organizations are areas that remain to be further investigated. Consequently, we call for more studies to investigate the role and activities of mediating agents in other contexts. We suggest that comparative studies on the emergence of different science-based fields within a similar institutional context would provide important insights on the contextual nature of agency and varying processes that induce local embedding of global science.

Furthermore, our analysis of the responses to one of the major health issues of the $21^{\text {st }}$ Century suggests that pressing contemporary social problems can only be addressed through collective and cross-national measures. However, our study indicated that individual agency underlies all mobilization activities both locally as well as across spatial scales. This poses an intriguing theoretical question as to what is the relationship between "collective institutional entrepreneurship” (Wijen \& Ansari, 2007) and individual agency. Studying the relationship between individual and collective agency by a processual case study approach, would likely result in theoretical insights on the mobilization for institutional change, as well as could help in finding practical solutions to urgent issues. 


\section{References}

Ainamo, A. \& Tienari, J. (2002). The rise and fall of a local version of management consulting in Finland. In M. Kipping \& L. Engwall (Eds.) Management consulting: Emergence and dynamics of a knowledge Industry (pp.70-87). Oxford: Oxford University Press.

Amin, A. \& Cohendet, P. (2004). Architectures of knowledge: Firms, capabilities and communities. Oxford: Oxford University Press.

Ansell, C. K. (1997). Symbolic networks: The realignment of the French working class, 18871894. American Journal of Sociology, 103 (2), 359-390.

Barley, S. R. \& Tolbert, P. S. (1997). Institutionalization and structuration: Studying the links between action and institution. Organization Studies, 18 (1), 93-117.

Beckert, J. (1999). Agency, entrepreneurs, and institutional change: The role of strategic choice and institutionalized practices in organizations. Organization Studies, 20 (5), 777-799.

Benford, R. D. \& Snow, D. A. (2000). Framing processes and social movements: An overview and assessment. Annual Review of Sociology, 26 611-639.

Blackburn, H. (2006). The Seven Countries Study. Objectives and History. Boletim da SPHM. $21(4), 32-35$.

Boxenbaum, E. (2006). Lost in translation: The making of Danish diversity management. American Behavioral Scientist, 49 (7), 939-948.

Buck, T. and Shahrim, A. (2005). The translation of corporate governance changes across national cultures: the case of Germany. Journal of International Business Studies, 36, (1), 42-61.

Bunnell, T. G. \& Coe, N. M. (2001). Spaces and scales of innovation. Progress in Human Geography, 25 (4), 569-589.

Collinson, S. \& Wilson, D. (2006). Inertia in Japanese organizations: Knowledge management routines and failure to innovate. Organization Studies, 27(9), 1359-1388.

Czarniawska, B. \& Joerges, B. (1996). Travels of ideas. In B. Czarniawska \& G. Sevón (Eds.), Translating organizational change (pp. 13-48). Berlin: Walter de Gruyter.

Czarniawska, B. \& Sevón, G., (Eds) (2005). Global ideas. How ideas, objects and practices travel in the global economy. Malmö: Liber \& Copenhagen Business School Press.

Déjean, F. Gond, J-P. \& Leca, B. (2007). Measuring the unmeasured-An institutional entrepreneur strategy in an emerging industry. Human Relations, 57(6), 741-764.

DiMaggio, P. (1988). Interest and agency in institutional theory. In L. B. Zucker (Ed.), Institutional patterns and organizations: Culture and environment (pp. 3-21). Cambridge, MA: Ballinger.

Djelic, M.-L. \& Ainamo, A. (2005). The telecom industry as cultural industry? The transposition of fashion logics into the field of mobile telephony. Research in Sociology of Organizations, 23: 45-80.

Dubois, A. \& Araujo, L. 2004. Research methods in industrial marketing studies. In H. Håkansson, D. Harrison \& A. Waluszewski, (Eds.), Rethinking marketing: Developing a new understanding of markets (pp. 207-227). Chichester :Wiley.

Dubois, A. \& Gadde, L.-E. (2002). Systematic combining: an abductive approach to case research. Journal of Business Research, 55, 553-560.

Ebrahim, S. \& Smith, G.D. (2001). Editors' Response - exporting failure. International Journal of Epidemiology, 30 (1): 1496-1497.

Edwards, T. \& Jones, O. (2008). Failed institution building: Understanding the interplay between agency, social skill and context. Scandinavian Journal of Management, 24 (1), 44-54. 
Fligstein, N. (1997). Social skill and institutional theory. American Behavioral Scientist, 40 (4), 397-405.

Frickel, S. \& Gross, N. (2005). A general theory of scientific/intellectual movements. American Sociological Review 70 (April), 204-232.

Garud, R., Hardy, C. \& Maguire, S. (2007). Institutional entrepreneurship as embedded agency: An introduction to the special issue. Organization Studies, 28 (7), 957-969.

Garud, R., Jain, S. \& Kumaraswamy, A. (2002). Institutional entrepreneurship in the sponsorship of common technological standards: The case of Sun Microsystems and Java. Academy of Management Journal, 45 (1), 196-214.

Gieryn, T. F. (1983). Boundary-work and the demarcation of science from non-science: Strains and interests in professional ideologies of scientists. American Sociological Review, 48 (6), 781-795.

Gieryn, T.F., Bevins, G.M. \& Zehr S.C. (1985). Professionalization of American scientists: Public science in the creation/evolution trials. American Sociological Review, 50 (3), 392-409.

Glynn, M.A., Barr, P.S. \& Dacin, M.T. (2000). Pluralism and the problem of variety. The Academy of Management Review, 25 (4), 726-734.

Golden-Biddle, K. \& Locke, K. D. (2006). Composing qualitative research. London: Sage.

Greenwood, R. \& Suddaby, R. (2006). Institutional entrepreneurship in mature fields: The big five accounting firms. Academy of Management Journal, 49 (1), 27-48.

Guler, I., Guillén, M.F. and Macpherson, J.M. (2002). Global competition, institutions, and the diffusion of ISO 9000 quality certificates. Administrative Science Quarterly, 47, 207-232.

Gullotta, T.B. \& Bloom, M. (2003). Encyclopedia of primary prevention and health promotion. New York: Kluver.

Haas, P. M. (1992). Introduction: Epistemic communities and international policy coordination. International Organization, 46 (1), 1-35.

Hargadon, A. B. \& Douglas, J.Y. (2001). When innovations meet institutions: Edison and the design of the electric light. Administrative Science Quarterly, 46, 476-501.

Hensmans, M. (2003). Social movement organizations: A metaphor for strategic actors in institutional fields. Organization Studies, 24(3), 355-381.

Hitt, M.A., Beamish, B.W., Jackson, S.E. (2007). Building theoretical and empirical bridges across levels: multilevel research in management. Academy of Management Journal, 50, 1385-1399.

Hoffman, A. J. (1999). Institutional evolution and change: environmentalism and the U.S. chemical industry. Academy of Management Journal, 42 (4), 351-371.

Holm, P. (1995). The dynamics of institutionalization: Transformation processes in Norwegian fisheries. Administrative Science Quarterly, 40(3), 398-422.

Hwang, H. \& Powell, W. W. (2005). Institutions and entrepreneurship. In S.A. Alvarez, R. Agarwal, \& O. Sorenson (Eds.), Handbook of entrepreneurship research: Disciplinary perspectives. New York, NY: Kluwer Publishers.

Institute of Medicine. (2001). Health and Behavior: The interplay of biological, behavioral, and societal influences. Washington, DC: the National Academies Press.

Karvonen, M. J.(2009). Prehistory of the North Karelia Project. In P. Puska, E. Vartiainen, T. Laatikainen, P. Jousilahti, and M. Paavola (Eds.). The North Karelia Project: From North Karelia to national action (pp. 15-18). Helsinki, Finland: National Institute for Health and Welfare.

Keys, A. (1952). The Cholesterol problem. Voeding, 13: 539-555.

Kuhn, T. (1962).The structure of scientific revolutions. Chicago: University of Chicago Press. 
Latour, B. (1986). The powers of association. In J. Law (Ed.), Power, action and belief: A new sociology of knowledge?(pp. 264-280), London: Routledge \& Kegan Paul.

Lawrence, T. B., Hardy, C. \& Phillips, N. (2002). Institutional effects of interorganizational collaboration: The emergence of proto-institutions. Academy of Management Journal, 45 (1), 281-290.

Lawrence, T. B. \& Phillips, N. (2004). From Moby Dick to Free Willy: Macro-cultural discourse and institutional entrepreneurship in emerging institutional fields. Organization, 11 (5), 689-711.

Lawrence, T. B. \& Suddaby, R. (2006). Institutions and institutional work. In S. Clegg, C. Hardy, W. Nord \& T. Lawrence (Eds.), Handbook of Organization Studies (pp. 215254). London: Sage.

Lefebvre, H. (1991). The production of space. Oxford: Blackwell.

Leitner, H. (1997). Reconfiguring the spatiality of power: The construction of a supranational migration framework for the European Union. Political Geography, 16 (2), 123-143.

Lindberg, K. \& Czarniawska, B. (2006). Knotting the action net, or organizing between organizations. Scandinavian Journal of Management, 22, 292-306.

Lippi, A. (2000). One theory, many practices. Institutional allomorphism in the managerialist reorganization of Italian local governments. Scandinavian Journal of Management, 16, 455-477.

Lounsbury, M. \& Crumley, E. T. (2007). New practice creation: An institutional perspective on innovation. Organization Studies, 28 (7), 993-1012.

Lounsbury, M. \& Ventresca, M. (2002). Social structure and organizations revisited. Research in the Sociology of Organizations, 19, 3-36.

Maguire, S. \& Hardy, C. (2009). Discourse and deinstitutionalization: The decline of DDT, Academy of Management Journal, 52 (1), forthcoming.

Maguire, S. \& Hardy, C. (2006). The emergence of new global institutions: A discursive perspective. Organization Studies, 27 (1), 7-29.

Maguire, S., Hardy, C. \& Lawrence, T. B. (2004). Institutional entrepreneurship in emerging fields: HIV/AIDS treatment advocacy in Canada. Academy of Management Journal, 47 (5), 657-679.

Mazur, A. (1987). Scientific disputes over policy. In H.T. Engelhardt. \& A.L. Caplan (Eds.), Scientific controversies. Case studies in the resolution and closure of disputes in science and technology (pp. 265-282). Cambridge: Cambridge University Press.

McAlister, A., Puska, P., Salonen, J.T., Tuomilehto, J. \& Koskela, K. (1982). Theory and action for health promotion: Illustrations from the North Karelia Project. American Journal of Public Health, 72 (1), 43-50.

McLaren, L. Ghali, L. Lorenzetti, D. \& Rock, M. (2007).Out of context? Translating evidence from the North Karelia project over place and time. Health Education Research, 22(3), 414-424.

Moore, K. (1996). Organizing integrity: American science and the creation of public interest organizations, 1955-1975. The American Journal of Sociology, 101 (6), 1592-1627.

Morrill, C. (2007). Institutional change and interstitial emergence: The growth of alternative dispute resolution in American law, 1965-95. In W. W. Powell \& D. L. Jones (Eds.), How institutions change. Chicago: University of Chicago Press.

Munir, K. A. (2005). The social construction of events: A study of institutional change in the photographic field. Organization Studies, 26 (1), 93-112.

Munir, K. A. \& Phillips, N. (2005). The birth of the Kodak moment: Institutional entrepreneurship and the adoption of new technologies. Organization Studies, 26 (11), 1665-1687. 
Mustaniemi, H. (2005). Saappaat savessa. Pohjois-Karjala projektin tuloksia tekemässä. (In Finnish: Boots in the mud. Making the results of the North-Karelia Project). PohjoisKarjala projektin tutkimussäätiö.

Nissinen, A., Berrios, X. \& Puska, P. (2001). Community-based noncommunicable disease interventions: lessons from developed countries for developing ones. Bulleting of the World Health Organization, 79, 963-970.

Perkmann, M. \& Spicer, A. (2007). 'Healing the scars of history': Projects, skills and field strategies in institutional entrepreneurship. Organization Studies, 28 (7), 1101-1122.

Pettigrew, A. (1990). Longitudinal field research on change: Theory and practice. Organization Science, 1 (3), 267-292.

Puska, P. (1999). The North Karelia Project: from community intervention to national activity in lowering cholesterol levels and CHD risk. European Heart Journal Supplements, 1 (Supplement S), R1-5.

Puska, P. (2008). The North Karelia Project: 30 years of successful prevention of chronic diseases. Diabetes Voice, 53 (May), 26-29.

Puska, P. (2009). WHOs work on chronic diseases prevention in relation to North Karelia Project and Finland. In P. Puska, E. Vartiainen, T. Laatikainen, P. Jousilahti \& M. Paavola (Eds.). The North Karelia Project: From North Karelia to national action (pp. 267-278). Helsinki, Finland: National Institute for Health and Welfare.

Puska, P., Tuomilehto, J., Nissinen, A. \& Vartiainen, E. (1995). The North Karelia Project. 20 year results and experiences. Helsinki: The National Public Health Institute.

Puska, P., Koskela, K., McAlister, A., Mäyränen, H., Smolander, A., Moisio, S. Viri, L., Korpelainen, V. \& Rogers, E.M. (1986). Use of lay opinion leaders to promote diffusion of health innovation in a community programme: lessons learned from the North Karelia project. Bulleting of the World Health Organization, 64(3), 437-446.

Puska, P., Nissinen, A. \& Vartiainen, E. (2009). International experiences with community based CVD prevention programmes and their evaluation. In In P. Puska, E. Vartiainen, T. Laatikainen, P. Jousilahti \& M. Paavola (Eds.). The North Karelia Project: From North Karelia to national action (pp. 243- 266). Helsinki, Finland: National Institute for Health and Welfare.

Puska, P. Vartiainen, E., Laatikainen, T., Jousilahti, P. \& Paavola, M. (2009) (Eds.). The North Karelia Project: From North Karelia to national action. Helsinki, Finland: National Institute for Health and Welfare.

Rao, H. (1998). Caveat emptor: The construction of non-profit consumer watchdog organizations. American Journal of Sociology, 103 912-961.

Rogers, E. M. (2003). Diffusion of Innovations. 5th edition. New York: Free Press.

Scott, W. R. (2001). Institutions and organizations. Second edition. Thousand Oaks: Sage

Seo, M.-G. \& Creed, W. E. D. (2002). Institutional contradictions, praxis, and institutional change: A dialectical perspective. Academy of Management Review, 27 (2), 222-247.

Siggelkow, N. 2007. Persuasion with case studies. Academy of Management Journal, 50(1), 20-24.

Spicer, A. (2006). Beyond the convergence-divergence debate: The role of spatial scales in transforming organizational logic. Organization Studies, 27 (10), 1467-1483.

Stake, R. E. (2005). Qualitative case studies. In N. K. Denzin \& Y. S. Lincoln (Eds.), The Sage Handbook of Qualitative Research (pp. 443-466). Thousand Oaks, CA: Sage.

Sundin, E. \& Tillmar, M. 2008. A nurse and a civil servant changing institutions: Entrepreneurial processes in different public sector organizations. Scandinavian Journal of Management, 24 (2), 113-124. 
Tempel, A., \& Walgenbach, P. (2007). Global standardization of organizational forms and management practices? What new institutionalism and the business-systems approach can learn from each other. Journal of Management Studies, 44(1), 1-24.

Van Maanen, J. Sørenson, J. \& Mitchell, T.R. (2007). Special topic on the interplay between theory and method. Academy of Management Review, 32(4), 1145-1154.

Weinehall, L. (2003). The emerging epidemic of cardiovascular disease history and background of the Northern Sweden initiative on cardiovascular disease. Scandinavian Journal of Public Health, 31(61): 5-8.

Wijen, F. \& Ansari, S. (2007). Overcoming inaction through collective institutional entrepreneurship: Insights from regime theory. Organization Studies, 28 (7), 10791100.

Zucker, L. \& Darby, M. (1997).Individual action and the demand for institutions: Star scientists and institutional transformation. The American Behavioral Scientist, 40 (4), 502-513. 


\begin{tabular}{|c|c|c|c|}
\hline Year & Event & Quotations exemplifying the global-local links & Key data sources \\
\hline $\begin{array}{l}\text { Inwar } \\
1954 \\
1958 \\
1970\end{array}$ & $\begin{array}{l}\text { Translation } \\
\text { Meeting of Martti J. Karvonen and Ancel Keys in Minnesota } \\
\text { Seven Countries Study on the epidemiology and causes of } \\
\text { heart disease begins at the University of Minnesota } \\
\text { WHO meeting in Rome considers possible approaches to } \\
\text { prevent heart disease }\end{array}$ & $\begin{array}{l}40 \text { years later it is difficult to understand how path- } \\
\text { breaking research it was. There was no model for it. } \\
\text { The Seven Countries Study developed into the classic } \\
\text { of epidemiology of heart disease. - Chairman of the } \\
\text { Finnish Heart Disease Association }\end{array}$ & $\begin{array}{l}\text { Interviews } \\
\text { History of the North Karelia Project } \\
\text { (Mustaniemi, 2005, Puska et al., 2009) } \\
\text { and History of the } 7 \text { Countries } \\
\text { Study (Blackburn, 2006, Puska et al., 2009) } \\
\text { www.epi.umn.edu/research/7countries }\end{array}$ \\
\hline $\begin{array}{l}\text { Local } \\
1956 \\
\\
1971 \\
1972 \\
1973 \\
\\
1976 \\
1977 \\
1988 \\
1995 \\
1997\end{array}$ & $\begin{array}{l}\text { Community and Movement Creation } \\
\text { Pre-study of the } 7 \text { Countries Study in eastern and } \\
\text { south-western Finland } \\
\text { Petition signed for urgent measures in North Karelia } \\
\text { North Karelia Project starts } \\
\text { WHO Director General Halfdan Mahler and Department } \\
\text { Head Zbynek Pisa visit the North Karelia } \\
\text { Project } \\
\text { Training for lay opinion leaders starts } \\
\text { North Karelia Project adopted at the national level } \\
\text { The 'Great Fat Debate' begins at the main Finnish } \\
\text { newspaper Helsingin Sanomat } \\
\text { Launch of the cholesterol-lowering functional food margarine } \\
\text { North Karelia Project ends }\end{array}$ & $\begin{array}{l}\text { Before launch of the project, Puska [leader of the } \\
\text { North Karelia Project]made a wide visit to Sweden, } \\
\text { England, Germany and Swizerland. (Mustaniemi, } \\
\text { 2005:72) } \\
\text { I've been working with the guru of innovation- } \\
\text { diffusion theory Rogers over the years. I visited } \\
\text { Stanford with him and he visited our cottage and we } \\
\text { wrote together about the use of lay opinion leaders - } \\
\text { Director and Principal Investigator of the North } \\
\text { Karelia Project }\end{array}$ & $\begin{array}{l}\text { Interviews } \\
\text { History of the North Karelia Project } \\
\text { (Mustaniemi, 2005, Puska et al., 2009) } \\
\text { and the Great Fat Debate } \\
\text { (Karvonen \&Vuokila, 2000) } \\
\text { Journal articles (e.g. Puska et al., 1986, } \\
\text { 1995; Puska, 2008, McAlister et al., 1982) }\end{array}$ \\
\hline $\begin{array}{l}\text { Outwo } \\
1976 \\
1979 \\
1991 \\
1995 \\
1999 \\
2000 s \\
2004 \\
2007\end{array}$ & $\begin{array}{l}\text { ard Translation } \\
\text { WHO Guidelines for Comprehensive Cardiovascular } \\
\text { Community Control Programmes } \\
\text { International Visitors' Programme of the North Karelia } \\
\text { Project starts } \\
\text { Early experiments with Benecol released at the scientific } \\
\text { meeting of the American Heart Association } \\
\text { New England Journal of Medicine publishes results that } \\
\text { Benecol lowers blood (LDL) cholesterol by 14\% } \\
\text { Launch of Benecol and Unilever's competing plant sterol } \\
\text { ester margarine in the USA } \\
\text { Increased replication of the NKP model internationally } \\
\text { WHO Global Strategy on Diet, Physical Activity and } \\
\text { Health } \\
\text { Finnish export organization Finpro exports Finnish } \\
\text { knowledge on health promotion [North Karelia Project] } \\
\text { to Asia }\end{array}$ & $\begin{array}{l}\text { They had decided that they'll establish a heart disease } \\
\text { prevention unit and they asked if I could join for 1-2 } \\
\text { years as I had over } 10 \text { years experience - } \\
\text { Co-principal Investigator of the North Karelia } \\
\text { Project } \\
\text { It is even amusing sometimes when I listen to } \\
\text { ministers from the [most distant] countries at the } \\
\text { WHO meetings talk about the North-Karelia Project. } \\
\text { - Director and Principal Investigator of the North } \\
\text { Karelia Project } \\
\text { The issue [high prevalence of heart disease] was } \\
\text { identified there [in Asia] and they were motivated, } \\
\text { we just had to offer a solution what we have done in } \\
\text { Finland. -Senior Consultant of a Finnish Export } \\
\text { Organization }\end{array}$ & $\begin{array}{l}\text { Interviews } \\
\text { WHO documents (e.g. strategy } \\
\text { documents and resolutions), } \\
\text { Journal articles (e.g. McLaren et al., 2007; } \\
\text { Puska et al., 1995) } \\
\text { History of the North Karelia Project } \\
\text { (Mustaniemi, 2005; Puska et al., 2009) } \\
\text { PUBMED } \\
\text { (http://www.ncbi.nlm.nih.gov/pubmed/) }\end{array}$ \\
\hline
\end{tabular}

Figure 1: Institutional Entrepreneurs as Translating Agents across Spatial Scales

\section{GLOBAL SCIENTIFIC COMMUNITY}

\section{Translating \\ activities of \\ institutional \\ entrepreneurs across scales}

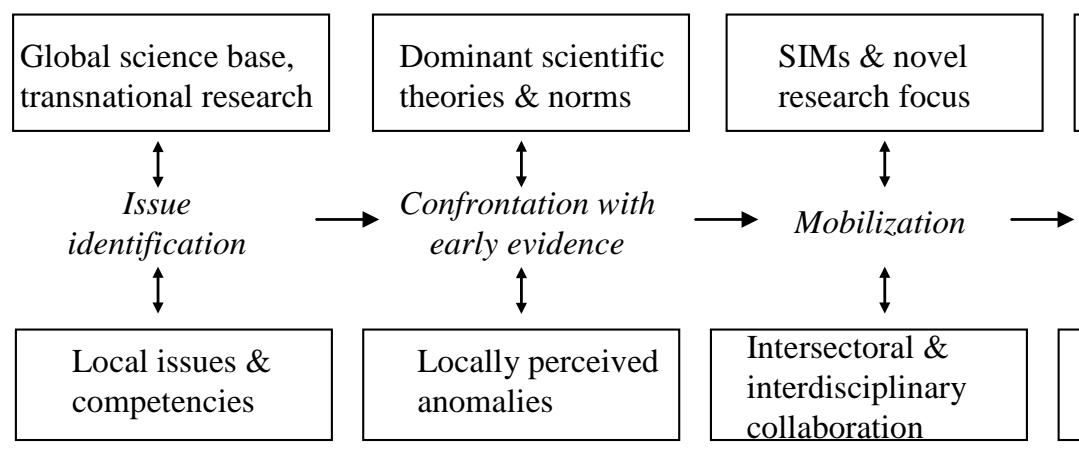

Global recognition and legitimacy

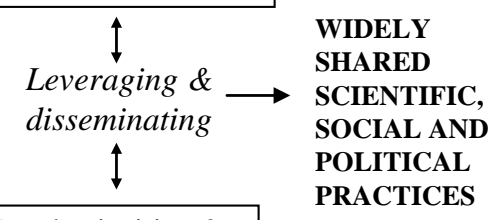

Novel priorities \& practices

\section{LOCAL INSTITUTIONS}

